


\section{Glasilo Future}

\section{Stručno-znanstveni časopis}

Nakladnik:

FUTURA

\section{FUTURA}

Sjedište udruge: Šibenik

\section{Adresa uredništva:}

Bana Josipa Jelačića 13 a, 22000 Šibenik, Hrvatska / Croatia

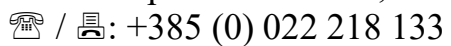

凶: urednistvo@gazette-future.eu / editors@gazette-future.eu

(3): www.gazette-future.eu

Uređivački odbor / Editorial Board:

Doc. dr. sc. Boris Dorbić, v. pred. - glavni i odgovorni urednik / Editor-in-Chief

Emilija Friganović, dipl. ing. preh. teh., v. pred. - zamjenica g. i o. urednika / Deputy Editor-in-Chief

Ančica Sečan Matijaščić, mag. act. soc. - tehnička urednica / Technical Editor

Antonia Dorbić, mag. art. - zamjenica tehničke urednice / Deputy Technical Editor

Prof. dr. sc. Željko Španjol

Mr. sc. Milivoj Blažević

Vesna Štibrić, dipl. ing. preh. teh.

Međunarodno uredništvo / International Editorial Board:

Prof. dr. sc. Kiril Bahcevandziev - Portugal (Instituto Politécnico de Coimbra)

Prof. dr. sc. Martin Bobinac - Srbija (Šumarski fakultet Beograd)

Prof. dr. sc. Zvezda Bogevska - Sjeverna Makedonija (Fakultet za zemjodelski nauki i hrana Skopje)

Dario Bognolo, mag. ing. - Hrvatska (Veleučilište u Rijeci)

Prof. dr. sc. Agata Cieszewska - Poljska (Szkoła Główna Gospodarstwa Wiejskiego w Warszawie)

Dr. sc. Bogdan Cvjetković, prof. emeritus - Hrvatska (Agronomski fakultet Zagreb)

Prof. dr. sc. Duška Ćurić - Hrvatska (Prehrambeno-biotehnološki fakultet Zagreb)

Prof. dr. sc. Margarita Davitkovska - Sjeverna Makedonija (Fakultet za zemjodelski nauki i hrana Skopje)

Prof. dr. sc. Dubravka Dujmović Purgar - Hrvatska (Agronomski fakultet Zagreb)

Prof. dr. sc. Josipa Giljanović - Republika Hrvatska (Kemijsko-tehnološki fakultet u Splitu)

Prof. dr. sc. Semina Hadžiabulić - Bosna i Hercegovina (Agromediteranski fakultet Mostar)

Prof. dr. sc. Péter Honfi - Mađarska (Faculty of Horticultural Science Budapest)

Prof. dr. sc. Valeria Ivanova - Bugarska (Fakultet za lozaro - gradinarstvo Plovdiv)

Prof. dr. sc. Mladen Ivić - Bosna i Hercegovina (Univerzitet PIM)

Doc. dr. sc. Orhan Jašić - Bosna i Hercegovina (Filozofski fakultet Tuzla)

Prof. dr. sc. Tajana Krička - Hrvatska (Agronomski fakultet Zagreb)

Doc. dr. sc. Dejan Kojić - Bosna i Hercegovina (Univerzitet PIM)

Slobodan Kulić, mag. iur. - Srbija (Srpska ornitološka federacija i Confederation ornitologique mondiale)

Prof. dr. sc. Biljana Lazović - Crna Gora (Biotehnički fakultet Podgorica)

Doc. dr. sc. Zvonimir Marijanović - Republika Hrvatska (Kemijsko-tehnološki fakultet u Splitu)

Doc. dr. sc. Ana Matin - Hrvatska (Agronomski fakultet Zagreb)

Prof. dr. sc. Bosiljka Mustać - Hrvatska (Sveučilište u Zadru)

Hrv. akademik prof. dr. sc. Stanislav Nakić - Bosna i Hercegovina (Sveučilište Hercegovina Mostar)

Sandra Popović, mag. ing. - Srbija (Poljoprivredni fakultet Beograd)

Doc. dr. sc. Bojan Simovski - Sjeverna Makedonija (Šumarski fakultet Skopje)

Prof. dr. sc. Davor Skejić - Hrvatska (Građevinski fakultet Zagreb)

Doc. dr. sc. Milan Stanković - Srbija (Univerzitet u Kragujevcu)

Akademik prof. dr. sc. Refik Šećibović - Bosna i Hercegovina (Visoka škola za turizam i menadžment Konjic)

Prof. dr. sc. Andrej Šušek - Slovenija (Fakulteta za kmetijstvo in biosistemske vede Maribor)

Prof. dr. sc. Elma Temim - Bosna i Hercegovina (Agromediteranski fakultet Mostar)

Mr. sc. Merima Toromanović - Bosna i Hercegovina (Biotehnički fakultet Univerziteta u Bihaću)

Doc. dr. sc. Ivana Vitasović Kosić - Hrvatska (Agronomski fakultet Zagreb)

Doc. dr. sc. Ana Vujošević - Srbija (Poljoprivredni fakultet Beograd)

Prof. dr. sc. Vesna Židovec - Hrvatska (Agronomski fakultet Zagreb)

Lektura i grafička priprema: Ančica Sečan Matijaščić, mag. act. soc.

Objavljeno: 30. lipnja 2019. godine.

Časopis izlazi u elektroničkom izdanju dva puta godišnje, krajem lipnja i prosinca, a predviđena su i dva interdisciplinarna specijalna izdanja tijekom godine iz STEM i ostalih znanstvenih/umjetničkih područja.

Časopis je besplatan. Rukopisi i recenzije se ne vraćaju i ne honoriraju.

Umnožavanje (reproduciranje), stavljanje u promet (distribuiranje), priopćavanje javnosti, stavljanje na raspolaganje javnosti odnosno prerada u bilo kojem obliku nije dopuštena bez pismenog dopuštenja Nakladnika.

Sadržaj objavljen u Glasilu Future može se slobodno koristiti u osobne i obrazovne svrhe uz obvezno navođenje izvora. 


\section{Glasilo Future}

\section{Stručno-znanstveni časopis}

FUTURA - stručno-znanstvena udruga za promicanje održivog razvoja, kulture i međunarodne suradnje, Bana Josipa Jelačića 13 a, 22000 Šibenik, Hrvatska

(2019) $2(1-2) 01-76$

\section{SADRŽAJ:}

Izvorni znanstveni rad (original scientific paper)

Str.

Anarma Poprženović, Špela Pezdevšek Malovrh, B. Dorbić, E. Delić

Stavovi o društvenoj funkciji i općem stanju zelenila u Bihaću (Bosna i Hercegovina)

Attitudes on social function and overall status of greenery in the city of Bihać (Bosnia and

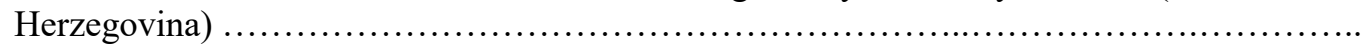

Aida Šukalić, Alma Rahimić, Vedrana Komlen, Alma Mičijević, Lamija Aliman

Sadržaj arsena u plodovima nektarine (Prunus persica var. nucipersica Schnied.) na području Hercegovine s procjenom rizika na zdravlje ljudi

The content of arsenic in nectarine fruit (Prunus persica var. nucipersica Schnied.) with risk assessment for human health on area of Herzegovina

Emilija Friganović, Martina Runje, Sara Ujaković, B. Dorbić, Mladenka Šarolić,

Duška Ćurić, Tajana Krička

Senzorska procjena tjestenine obogaćene proteinima konoplje i graška

Sensory evaluation of hemp and pea proteins enriched pasta

\section{Prethodno priopćenje (preliminary communication)}

B. Dorbić, Emilija Friganović, Marija Slipčević, Margarita Davitkovska, Zvezda Bogevska, Ana Vujošević

Senzorska procjena različitih oparaka od aromatičnog bilja

Sensory evaluation of different infusions from aromatic herbs

\section{Stručni rad (professional paper)}

Mladenka Šarolić, Josip Roguljić, Emilija Friganović, Žana Delić, Boris Dorbić, Marina Torić

Poljički soparnik

"Poljički soparnik".

\section{Nekategorizirani rad (uncategorised paper)}

\section{S. Kulić}

Kanarinac pjesme slavujar (Song Canary "Slavujar")

Popularan rad

Popular paper

Zdenka Bilušić

Prikaz konferencije

Review of conference

\section{B. Dorbić}

Društvene vijesti i obavijesti

Social news and announcements 


\title{
Poljički soparnik
}

\section{"Poljički soparnik"}

\section{Mladenka Šarolić $^{1 *}$, Josip Roguljić ${ }^{1,2}$, Emilija Friganović ${ }^{1}, \check{Z ̆ a n a ~ D e l i c ́ ~}^{1}$, Boris Dorbić ${ }^{1}$, Marina Torić ${ }^{3}$}

stručni rad (professional paper)

doi: $10.32779 /$ gf.2.1-2.5

\section{Sažetak}

U današnjem vremenu brzog razvoja te gotovo svakodnevnih promjena i napretka stari običaji i tradicijske vrijednosti padaju u zaborav te se javlja potreba za zaštitom tradicijske i nematerijalne kulturne baštine. Turizam u našem kraju kontinuirano napreduje i postaje glavnim motorom našeg gospodarstva. Cilj ovog rada je predstaviti vrijedan tradicijski hrvatski prehrambeni proizvod Poljički soparnik, pekarski proizvod izrađen od mekog pšeničnog brašna, blitve, crvenog luka, maslinovog ulja, češnjaka, soli i vode. U prošlosti je soparnik bio jedno od osnovnih jela i poznat samo u krajevima Poljica, a danas kao zaštićen proizvod svjedoči o nekadašnjem načinu života na selu te uopće o kulturi stola kao neizostavnom dijelu ukupne nacionalne kulture. Od proizvoda za siromašne postao je prepoznatljivi brend, te se nudi na svim kulturnim ili gastronomskim događanjima širom Dalmacije i Lijepe naše.

Ključne riječi: poljički soparnik, tradicijski proizvodi, kvaliteta, zaštita.

\begin{abstract}
In today's time of rapid development and almost daily change and progress, old traditions and traditional values fall into oblivion, and there is a need to protect traditional and intangible cultural heritage. Tourism in our region is continually advancing and becoming the main engine of our economy. The aim of this paper is to present a valuable traditional Croatian food product - "Poljički soparnik", a bakery product made from finely ground wheat flour, chard, red onion, olive oil, garlic, salt and water. In the past, the "soparnik" was one of the basic dishes and only known in the Poljica regions, and today, as a protected product, it attests to the former way of life in the rural regions and to the table culture as an indispensable part of the total national culture. From the products for the poor it has become a recognizable brand, and it is offered on all cultural or gastronomic events throughout Dalmatia and Croatia.

\footnotetext{
${ }^{1}$ Veleučilište "Marko Marulić" u Kninu, Odjel Poljoprivreda krša i Odjel Prehrambena tehnologija, Krešimirova 30, 22300 Knin, Republika Hrvatska.

* E-mail: msarolic@veleknin.hr.

${ }^{2}$ Završeni student preddiplomskog stručnog studija Prehrambena tehnologija.

${ }^{3}$ Poljoprivredna zadruga "Primošten Burni", Draga 6, 22202 Primošten Burni, Republika Hrvatska.
} 
Key words: "poljički soparnik", traditional products, quality, protection.

\section{Uvod}

Autohtoni prehrambeni proizvodi plijene pažnju potrošača na globalnom tržištu poljoprivrednoprehrambenih proizvoda zbog svoje kvalitete koja je rezultat sirovinskog sastava, proizvodnog postupka te karakterističnog zemljopisnog područja, a njihova zaštita uvelike podiže razinu konkurentnosti proizvodnje i prepoznatljivosti regije ili zemlje iz koje potječu (Maleš, 2015). Nepovjerenje u kvalitetu i sigurnost proizvoda prisutnih na tržištu, podržavanje domaće proizvodnje i povjerenje u kvalitetu domaćih proizvoda razlozi su povećane potražnje za tradicijskim proizvodima (Kovačić, 2005).

\section{Zaštićeni proizvodi}

Republika Hrvatska zbog posebnosti zemljopisnog položaja, prirodnih i klimatskih uvjeta kao i bogate kulture te tradicije, posjeduje veliki broj autohtonih prehrambenih proizvoda koji zbog tehnoloških, prehrambenih $i$ organoleptičkih specifičnosti, kvalitetom i posebnošću uspješno konkuriraju na hrvatskom tržištu i dio su naše gastronomske ponude. Mnogi od njih su postali prepoznatljivi kao $i$ zemljopisna područja u kojima se proizvode. Proizvodi se štite zbog više cjenovne kategorije te stvaranja identiteta i prepoznatljivosti. Zaštitom se povezuje proizvod s određenim zemljopisnim područjem što doprinosi prepoznatljivost i razvoju tog područja ${ }^{4}$.

Na svjetskom tržištu prehrambenih proizvoda trguje se mnoštvom proizvoda različite kvalitete i cijene, a ponekad i upitne kvalitete i zdravstvene ispravnosti. Proizvodi iznimne kvalitete ne mogu konkurirati cjenovno povoljnijim proizvodima. Zaštita proizvoda je i alat promocije i garancija da proizvod doista odgovara deklariranoj razini kvalitete, a ujedno i zaštita imena proizvoda od zlouporabe i imitacije. Potrošači cijene proizvode za koje mogu biti sigurni da znaju što kupuju (Sladonja et al., 2006.). Tradicijski proizvodi su jedna od konkurentskih prednosti hrvatskog sela. Manji dio ovih proizvoda ima izvozni potencijal, a najveći dio je važan za nacionalno odnosno lokalno tržište i turističku ponudu (Kovačić et al., 2005, str. 154). Centralno mjesto u ruralnom području čini poljoprivreda, te će povećanje konkurentnosti ove gospodarske djelatnosti ovisiti o oživljavanju ruralnog gospodarstva (Zmaić et al., 2011.). Proizvodi s oznakom zemljopisnog podrijetla daju dodatnu vrijednost ruralnom prostoru na kojem su zaštićeni, usmjereni su revalorizaciji autohtonog asortimana, a neposredno imaju i pozitivan utjecaj na razvoj turizma, glavne pokretačke snage hrvatskog gospodarstva (Sladonja et al., 2006, str. 187).

Zaštićeni proizvodi kao i oni u postupku zaštite objavljeni su u DOOR [Database of Origin and Registration (eng.)] bazi podataka o podrijetlu i registraciji proizvoda. DOOR baza trenutno sadrži

\footnotetext{
${ }^{4}$ Posjećeno 14. 09. 2018. na mrežnim stranicama Središnjeg državnog portala Vlade Republike Hrvatske: https://gov.hr/print.aspx?id=1614\&url=print.
} 
1472 zaštićenih proizvoda. Od toga je 651 zaštićeno oznakom izvornosti, 758 zaštićeno oznakom zemljopisnog podrijetla i 63 oznakom zajamčeno tradicionalnog podrijetla ${ }^{5}$. Republika Hrvatska je do sada na razini Europske unije registrirala i zaštitila jednom od oznaka 23 proizvoda.

Zaštićene oznake izvornosti dobilo je 12 hrvatskih proizvoda: Paška sol, Ekstra djevičansko maslinovo ulje Cres, Neretvanska mandarina, Ogulinski kiseli kupus/Ogulinsko kiselo zelje, Istarski pršut/Istrski pršut, Krčko maslinovo ulje, Korčulansko maslinovo ulje, Paška janjetina, Šoltansko maslinovo ulje, Varaždinsko zelje, Slavonski med i Istra (ekstra djevičansko maslinovo ulje).

Oznakom zemljopisnog podrijetla zaštićeno je 11 proizvoda: Zagorski mlinci, Krčki pršut, Baranjski kulen, Lički krumpir, Drniški pršut, Dalmatinski pršut, Poljički soparnik/ Poljički zeljanik/Poljički uljenjak, Zagorski puran, Slavonski kulen/Slavonski kulin, Međimursko meso 'z tiblice i Lička janjetina.

U kategoriji 2.4. Kruh, tjestenina, kolači keksi i ostalo na razini EU do sada je ukupno registriran 81 proizvod. U toj kategoriji u Republici Hrvatskoj za sada se nalaze samo Poljički soparnik i Zagorski mlinci.

\section{Poljica}

Poljica (Slika 1.), nekoć upravno-politički, a danas samo zemljopisno-povijesni pojam, prostor je od $248 \mathrm{~km}^{2}$ čije granice idu od ušća rijeke Cetine u Omišu do ušća rijeke Žrnovnice u Stobreču, potom Žrnovnicom pa preko planine Mosor do Cetine ispod Garduna blizu Trilja i zatim Cetinom do njenog uvira u more u Omišu. Sam morfonim Poljica označava mala polja, zemlju u škrapama, izvor života u kamenitoj goleti (Kuvačić-Ižepa, 2002.).

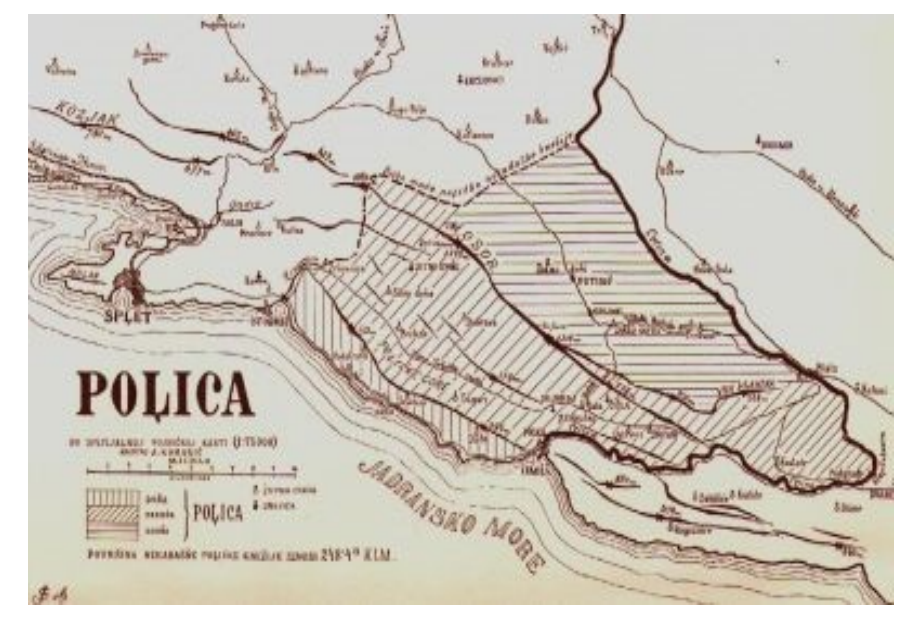

Slika 1. Poljička Republika ${ }^{6}$.

Figure 1. The Republic of Poljica ${ }^{6}$.

\footnotetext{
${ }^{5}$ Posjećeno 28. 06. 2019. na mrežnim stranicama DOOR baze podataka o podrijetlu i registraciji proizvoda: http://ec.europa.eu/agriculture/quality/door/list.html.

${ }^{6}$ Posjećeno 12. 09. 2018. na mrežnim stranicama http://www.almissa.com/poljickarepublika.htm.
} 


\section{Povijest Poljičkog soparnika}

Poljički soparnik je obredni svečani pekarski proizvod s područja nekadašnje Poljičke Republike, čija proizvodnja datira još iz doba turskih pohoda na priobalje i Dalmatinsku zagoru (Šimunović-Petrić, 1992). Iz priča i dostupnih starih zapisa zaključuje se kako je bio proizvod namijenjen siromašnima te posno soparno - suhoparno jelo koje se pripremalo u dane posta, Veliki petak, Badnji dan i uoči blagdana Svih Svetih, a pripremao se i za težake i goste. Oskudne prilike područja Poljica (plitka tla, ekstremne vrućine i suša) dovodile su stanovništvo do neimaštine i siromaštva, a domišljate i vješte Poljičke žene od jednostavnih sirovina započele su proizvodnju poljičkog soparnika koja se prenosila s generacije na generaciju (Rodić i Tićinović, 2015). Danas soparnik predstavlja cjelokupnu povijest Poljičkog kraja pa ga je tako Ministarstvo kulture rješenjem od 03. rujna 2007. g. proglasilo nematerijalnim kulturnim dobrom, odnosno priprema tradicijskog jela soparnik nalazi se na listi zaštićenih nematerijalnih kulturnih dobara ${ }^{7,8}$, a 30. ožujka 2016. godine Europska komisija objavljuje da je Poljički soparnik dobio zaštićenu oznaku zemljopisnog podrijetla na razini EU (Rodić, 2017.).

\section{Opis proizvoda}

Poljički soparnik / Poljički zeljanik / Poljički uljenjak radi se od jednostavnih sirovina: mekog pšeničnog brašna, blitve, crvenog luka, maslinovog i miješanog (maslinovo i suncokretovo ulje u omjeru 1:1) ulja, češnjaka, soli i vode. To je pekarski proizvod od razvaljanog tijesta ispunjen blitvom i crvenim lukom (kapulom), a ispečen na užarenom kominu u žeravi s lugom (na žaru posut pepelom). Okruglog je oblika, promjera od 90 do 110 centimetara ovisno o promjeru sinije (okrugla daska). Nakon pečenja, maže se maslinovim uljem i sitno sjeckanim ili stučenim češnjakom. Ispečen i namazan reže se na način da se dobiju komadi (fete) romboidnog oblika. Rubni komadi (okrajci) su nepravilnog oblika i s uvrnutim rubom. Boje je svijetložute do svijetlo zelene, mjestimično nagorjele i popucale kore. Mirisa pečenog tijesta, maslinovog ulja, češnjaka, te drva izgaranog na otvorenoj vatri. Sastojci za izradu nabavljaju se na tržištu ili s vlastitog OPG-a, a postupak proizvodnje u cijelosti treba biti tradicionalan i u određenom zemljopisnom području (Rodić i Tićinović, 2015).

\footnotetext{
7 "Zaštićena kulturna dobra nematerijalne baštine predstavljaju oblike kulturnog izričaja od osobite važnosti na određenom prostoru, njihova koncentracija odnosno disperzija svjedoči njihovu povijesnu ukorijenjenost posebice u tradicijskoj kulturi nematerijalne kulturne baštine osobite vrijednosti ili popularne $i$ tradicijske izričaje iznimne vrijednosti s povijesnog, umjetničkog, etnografskog, sociološkog, antropološkog, lingvističkog ili književnog aspekta.". Posjećeno 01. 06. 2019. na mrežnim stranicama Ministarstva kulture: https://minkulture.hr/?id=251.

${ }^{8}$ Opis dobra: "Priprema tradicijskog jela soparnik, simbola nekadašnje Poljičke republike, iziskuje umješnost žena koje ga i danas pripremaju pekući ga pokrivenog lugom na užarenom kominu. Sprema se i na prostorima koje su Poljičani dobili kao zasluge za protuturske borbe i mjestima gdje su ga Poljičanke prenijele udajom. U prošlosti se pripremao kao posno jelo i u prigodama čašćenja. Jednostavni su sastojci - brašno, blitva, crveni luk, maslinovo ulje i češnjak (poneka sela dodaju još neke sastojke), a potrebna je vještina da bi se tanko razvukle kore $i$ osobito da bi se pomoću sinija postavio na komin bez da se izobliči. Na ispečeni se utrlja maslinovo ulje i zgnječeni češnjak, reže se u formi romboida.". Posjećeno 01. 06. 2019. na mrežnim stranicama Ministarstva kulture: https:/www.min-kulture.hr/default.aspx?id=6212\&kdId=367910280.
} 


\section{Tehnološki proces proizvodnje}

Tehnološki proces proizvodnje Poljičkog soparnika (Slika 2.) sastoji se od niza operacija koje počinju pripremom sirovine, prije svega čišćenjem i pranjem blitve. Bitno je koristiti stariju blitvu koja sadrži manje vode, a nakon usitnjavanja potrebno ju je dobro prosušiti te se ova operacija obavi često i dan ranije.

Tablica 1. prikazuje okvirni tehnološki normativ za proizvodnju soparnika. U njoj su sadržane osnovne i pomoćne sirovine, ostali repromaterijal, energenti i trošak radne snage. Najveća stavka u proizvodnoj cijeni je trošak rada jer se radi isključivo o ručnoj proizvodnji. Prodajna cijena soparnika, prema informacijama od nekoliko proizvođača, kreće se u rasponu od 200 - 250 kn po komadu.

Tablica 1. Tehnološki normativ za proizvodnju soparnika (Roguljić, 2018).

Table 1. Technological normative for the soparnik production (Roguljić, 2018).

\begin{tabular}{|c|c|c|c|c|c|}
\hline Red. br. & Vrsta i naziv troška & Jed. mjere & $\begin{array}{l}\text { Utrošak za jedinicu } \\
\text { proizvoda }\end{array}$ & $\begin{array}{c}\text { Cijena (kn) } \\
(\mathrm{kn} / \text { jed. mjere })\end{array}$ & $\begin{array}{c}\text { Cijena ukupno } \\
\text { (kn) }\end{array}$ \\
\hline \multirow{11}{*}{1.} & SIROVINE & & & & \\
\hline & Blitva & $\mathrm{kg}$ & 2,5 & 8 & 20,0 \\
\hline & Brašno & $\mathrm{kg}$ & 1,5 & 4 & 6,0 \\
\hline & Crveni luk (kapula) & $\mathrm{kg}$ & 0,1 & 2,5 & 0,25 \\
\hline & Bijeli luk & $\mathrm{kg}$ & 0,05 & 40 & 2,0 \\
\hline & Maslinovo ulje & $\mathrm{L}$ & 0,325 & 40 & 13,0 \\
\hline & Suncokretovo ulje & $\mathrm{L}$ & 0,125 & 10 & 1,25 \\
\hline & Voda & $\mathrm{m}^{3}$ & 0,0005 & 9,42 & 0,005 \\
\hline & Sol & $\mathrm{kg}$ & 0,06 & 5 & 0,30 \\
\hline & Stretch folija & $\mathrm{m}$ & 5 & 0,25 & 1,25 \\
\hline & Sredstvo za pranje & $\mathrm{L}$ & 0,1 & 8 & 0,8 \\
\hline 2. & VODA & $\mathrm{m}^{3}$ & 0,01 & 9,42 & 0,1 \\
\hline 3. & EL. ENERGIJA & $\mathrm{kWh}$ & 0,5 & 0,53 & 0,265 \\
\hline 4. & DRVNA MASA & $\mathrm{m}^{3}$ & 0,2 & 200 & 40 \\
\hline 5. & RADNA SNAGA & sati rada & 2,0 & 25 & 50 \\
\hline \multicolumn{5}{|c|}{ UKUPNO (kn): } & 135,22 \\
\hline
\end{tabular}




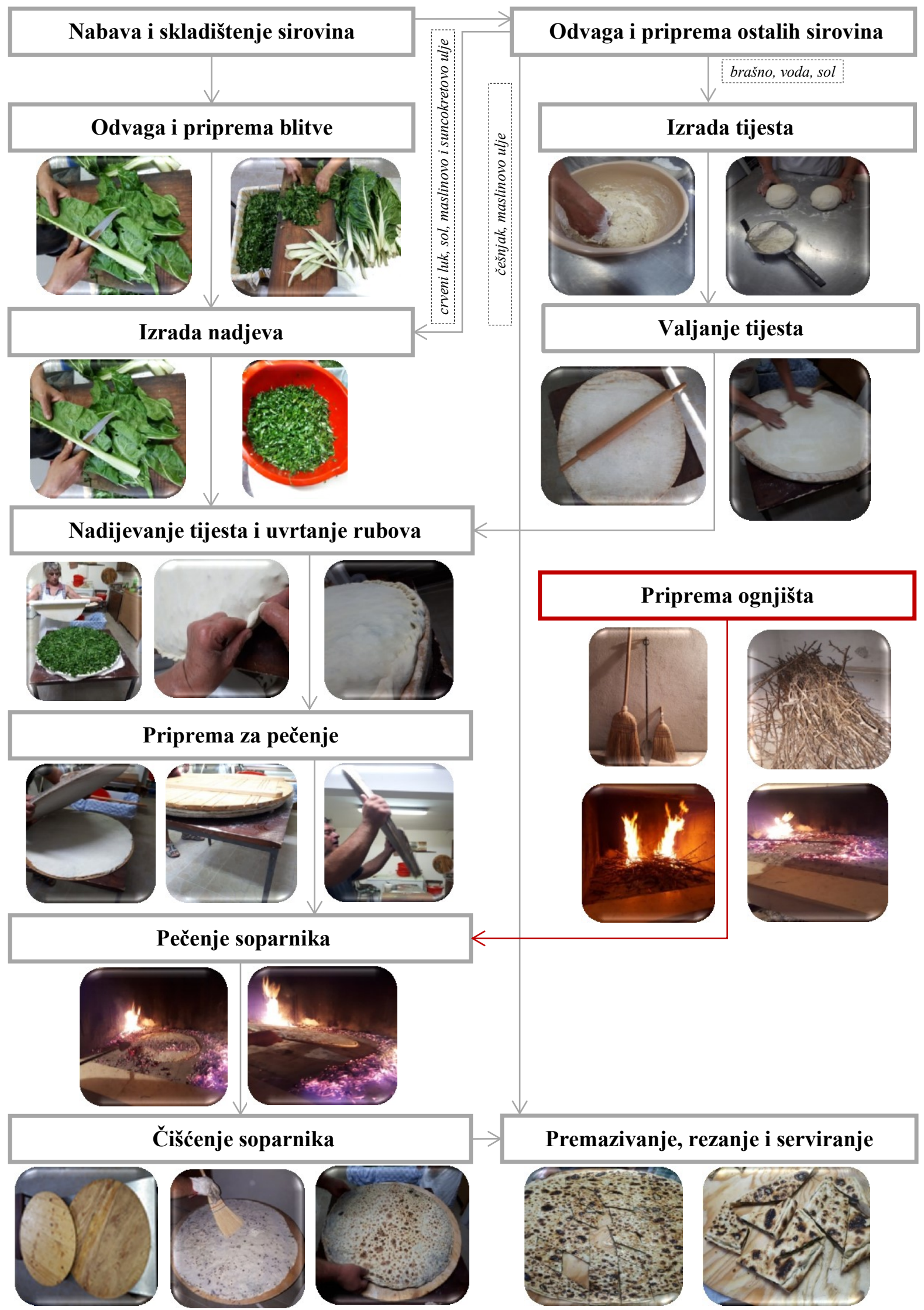

Slika 2. Dijagram toka procesa proizvodnje Poljičkog soparnika. Fotografije (Roguljić, 2018).

Figure 2. Flowchart of "Poljički soparnik" production process. Photos (Roguljić, 2018). 


\section{Prodaja i promocija}

Zbog sve većeg interesa domaćih potrošača i turističkog tržišta za tradicijskim i zaštićenim proizvodima povećan je i plasman tih proizvoda na tržište jer poljoprivredni proizvođači u njihovoj proizvodnji vide svoju poslovnu priliku, a kroz brojne manifestacije na kojima se predstavljaju izravno pridonose takvim trendovima (Mikšić et al., 2007). Soparnik je postao sastavni dio tradicionalne gastronomske ponude pa ga se tako nudi u brojnim restoranima i hotelima, organiziraju se razne manifestacije i natjecanja u izradi soparnika što povećava turističku i gastronomsku ponudu kraja. Najviše se prodaje ipak na kućnom pragu nekolicine OPG-a. Još uvijek nije kao gotovo jelo tj. pakovina prisutan u maloprodaji dijelom možda i zbog kratke trajnosti samog proizvoda. Zbog izuzetne potražnje i nastojanja da se ponuda proširi i u udaljenije krajeve ne samo Hrvatske bilo bi itekako korisno pronaći odgovarajuće ambalažne materijale i načine pakiranja kako bi se postigla dulja trajnost i očuvala svježina ovog iznimnog proizvoda.

\section{Zaključak}

Obogaćivanje ruralnog turizma proizvodnjom tradicijske hrane i hrane proizvedene po ekološkim principima omogućit će opstanak ruralnih prostora i obiteljskih poljoprivrednih gospodarstava. Povratak gotovo zaboravljenih okusa i mirisa u tradicionalnu dalmatinsku gastronomiju kao djela mediteranske nemoguć je bez poljoprivrednika i zelenih poduzetnika koji su u agrobioraznolikosti prepoznali svoju priliku za iskorak u novu poslovnu dimenziju i razvoj (Ozimec et al., 2015, str.76). Poljoprivredni proizvodi koji se promoviraju i vežu uz kulturnu i tradicijsku baštinu mogu postati generator razvoja velikog broja poljoprivrednih domaćinstava (Zmaić et al., 2011).

\section{Zahvala}

Rad je izrađen u okviru izrade Završnog rada Josipa Roguljića, bacc. ing. preh. teh. (vidi Literaturu).

\section{Literatura}

Kovačić, D. (2005). Izravna prodaja seljačkih proizvoda. Zagreb: Agrarno savjetovanje d.o.o.

Kovačić, D., Mesić, Ž., Cerjak, M. (2014). Hrvatski tradicijski proizvodi. Agroekonomika i ruralna sociologija, 49. hrvatski i 9. međunarodni simpozij agronoma, Dubrovnik,151-155.

Kuvačić-Ižepa, M. (1998). Poljica : putovanje kroz povijest i krajolik. Split: Naklada Bošković.

Maleš, N. (2015). Značenje i važnost zaštićene oznake izvornosti sira, maslinovog ulja i suhomesnatih proizvoda na globalnom tržištu, Završni rad, Agronomski fakultet Sveučilišta u Zagrebu. 
Mikšić, M., Nikolić, E., Borbaš, T., Murgić, N., Juzbašić, K., Pajić, S., Klarić, H., Peranić, I., Črep, R., Jelaković, K., Perić, B., Fumić, K. (2007). Katalog kalkulacija tradicijskih poljoprivrednoprehrambenih proizvoda. Zagreb: Hrvatski zavod za poljoprivrednu savjetodavnu službu, Odjel za agroekonomiku.

Ozimec, R., Karoglan Kontić, J., Maletić, E., Matotan, Z., Strikić, F. (2015). Tradicijske sorte i pasmine Dalmacije. UNDP - Projekt Coast.

Rodić, P., Tićinović, Đ. (2015). Specifikacija proizvoda "Poljički soparnik", "Poljički zeljanik", "Poljički uljenjak" - Oznaka zemljopisnog podrijetla. Omiš: Udruga "Poljički soparnik".

Rodić, P. (2017). Poljički soparnik - tradicijsko jelo - prezentat Poljica u Hrvatskoj i Hrvatske u svijetu. Zagreb, Forum: Sheme kvalitete hrane, zaštićena oznaka izvornosti, zemljopisnog podrijetla $i$ zajamčeno tradicionalnog specijaliteta.

Roguljić, J. (2018). Poljički soparnik, Završni rad, Veleučilište "Marko Marulić" u Kninu.

Sladonja, B., Radulović, M., Brkić, K., Krapac, M., Šetić, E. (2006). Oznaka izvornosti i zemljopisnog podrijetla maslina i maslinovog ulja u Hrvatskoj. Pomologia Croatica 12 (2), 175-188.

Šimunović-Petrić, Z. (1992). Soparnik kao obredno i svečano jelo u Poljicima. Ethnologica Dalmatica, 1 (1), 95-98.

Zmaić, K., Sudarić, T., Mikolčević, M. (2011). Dinamika, raznolikost i sinergija tradicijskih proizvoda u ruralnim područjima. Tranzicija 12 (25-26), 156-161.

http://ec.europa.eu/agriculture/quality/door/list.html. Posjećeno 28. 06. 2019.

https://gov.hr/print.aspx?id=1614\&url=print. Posjećeno 14. 09. 2018.

https://min-kulture.hr/?id=251. Posjećeno 01. 06. 2019.

http://www.almissa.com/poljickarepublika.htm. Posjećeno 12. 09. 2018.

https://www.min-kulture.hr/default.aspx?id=6212\&kdId=367910280. Posjećeno 01. 06. 2019.

Primljeno: 10. lipnja 2019. godine

Prihvaćeno: 30 . lipnja 2019. godine
Received: Jun 10, 2019

Accepted: Jun 30, 2019 